\title{
Characterization and Performance Test of Palm Oil Based Bio-Fuel Produced Via Ni/Zeolite-Catalyzed Cracking Process
}

\author{
Sri Kadarwati* and Sri Wahyuni
}

${ }^{a}$ Department of Chemistry, Semarang State University, Kampus Sekaran Gunungpati Semarang 50229, Central Java, Indonesia

\begin{abstract}
Catalytic cracking process of palm oil into bio-fuel using Ni/zeolite catalysts (2-10\% wt. Ni) at various reaction temperatures $\left(400-500^{\circ} \mathrm{C}\right)$ in a flow-fixed bed reactor system has been carried out. Palm oil was pre-treated to produce methyl ester of palm oil as feedstock in the catalytic cracking reactions. The Ni/zeolite catalysts were prepared by wetness impregnation method using $\mathrm{Ni}\left(\mathrm{NO}_{3}\right)_{2} \cdot 6 \mathrm{H}_{2} \mathrm{O}$ as the precursor. The products were collected and analysed using GC, GC-MS, and calorimeter. The effects of process temperatures and $\mathrm{Ni}$ content in $\mathrm{Ni} /$ zeolite have been studied. The results showed that $\mathrm{Ni}-2 /$ zeolite could give a yield of $99.0 \%$ at $500^{\circ} \mathrm{C}$ but only produced gasoline fraction of $18.35 \%$. The physical properties of bio-fuel produced in this condition in terms of density, viscosity, flash point, and specific gravity were less than but similar to commercial fuel. The results of performance test in a 4-strike engine showed that the mixture of commercial gasoline (petrol) and bio-fuel with a ratio of 9:1 gave similar performance to fossil-based gasoline with much lower $\mathrm{CO}$ and $\mathrm{O}_{2}$ emissions and more efficient combustion.
\end{abstract}

Keywords: bio-fuel, characterization, $\mathrm{Ni} /$ zeolite, palm oil, performance

Article History: Received Sept 17, 2014; Received in revised form Dec 16, 2014; Accepted February 10, 2015; Available online How to Cite This Article: Kadarwati, S., and Wahyuni, S.(2015).Characterization and Performance Test of Palm Oil Based Bio-Fuel Produced Via $\mathrm{Ni}$ /Zeolite-Catalyzed Cracking Process. Int. Journal of Renewable Energy Development, 4(1), 32-38. http://dx.doi.org/10.14710/ijred.4.1.32-38

\section{Introduction}

The increase of world wide energy demand causes the depletion of fossil-based petroleum fuels. Due to its non reneawable properties, exploration on a renewable fuel source, inexpensive, abundant, biodegradable, and environmentally friendly is paid more attention. Extensive research on the production of liquid fuels have been done using various raw materials such as sunflower seed oil (Demirbas 2003), used cooking oil (Styles 2003; Handoko 2006), canola oil (Idem et al. 1997), palm oil (Kadarwati and Wahyuni 2011; Sang 2003; Nasikin et al. 2009; Siregar and Amin 2006; Siswanto et al. 2008; Twaiq et al. 1999; Twaiq et al. 2003; Wijanarko et al. 2006), and vegetable oils (Kloprogge et al. 2005). Two main fractions are paid intensive attention in the production of bio-fuel, i.e. diesel fraction (Demirbas 2003; Style 2005; Twaiq et al. 1999; Twaiq et al. 2003; Sang, 2003; Kloprogge et al.
2005; Idem et al. 1997) which does not require high temperatures in order to lower production costs and gasoline fraction. The production of gasoline fraction from renewable materials is a challenging process due to its more strict requirements (e.g. requires higher temperature process and the presence of hydrogen) compared to that of diesel fraction, which require a higher cost production. However, as the gasoline fraction is widely used as liquid fuels, the production of renewable gasoline fraction is important to further substitute the fossil-based gasoline fraction.

Palm oil is one of renewable sources which can be converted to bio-fuels. It mainly contains palmitic acid (16:0) and oleic acid (18:1). Esterification of palm oil by reaction with methanol will result in methyl esters of palm oil which is also called as bio-diesel. This methyl ester is suitable for diesel engine (Choo and Ma 1996). However, for gasoline engine, this methyl ester needs to be further processed to meet the requirements of

*Corresponding Author: Phone: +61 452491411

Email: sri_kadarwati@yahoo.co.id 
gasoline engine. It was observed in our preliminary study that palm oil without esterifaction treatment was more difficult to convert directly to bio-fuel with high gasoline fraction. Further catalytic cracking process of methyl ester of palm oil is necessary to deoxygenate it to make it compatible as a fuel due to the large amounts of oxygen (Yakovlev et al. 2009) and crack the heavy hydrocarbons to the light ones. On the other hand, Indonesia natural zeolite has a great potential as a cracking catalyst (Handoko 2006; Nasikin et al. 2009). the modification of the zeolite such as acid treatment and impregnation of active metals can improve the activity of the zeolite (Handoko 2006; Nasikin et al. 2009; Kadarwati and Wahyuni 2011).

Thermal cracking at high temperatures of vegetable oils, animal fat, natural fatty acids, and methyl esters of fatty acids will produce lighter hydrocarbon fractions (light hydrocarbons) (Style 2003). This hydrocarbon light fraction is bio-fuel containing gasoline and diesel fraction with the percentage of the former was higher than that of the latter. Palm oil can also be thermally cracked at high temperatures into hydrocarbons which can be used as an alternative fuel for clean fuel engines (Demirbas 2003). The use of catalysts during the process is very important to keep a low production cost due to high temperature process. Catalysts with pores in the mesoporous region, high $\mathrm{Si} / \mathrm{Al}$ ratio, and high surface area are very effective in the reaction of long carbon chain termination in palm oil to produce diesel fraction, even gasoline fraction (Twaiq et al. 2003). Catalytic cracking of palm oil, canola oil, and sunflower oil combined with deoxygenation reaction using pillared clay as a catalyst produced bio-fuel compounds consisting of gasoline, diesel and kerosene (Kloprogge et al. 2005), while palm oil cracking with zeolite catalysts type MCM-41 and in a fixed-bed reactor system at a temperature of $450^{\circ} \mathrm{C}$ resulted in bio-fuel with linear hydrocarbon compounds (straight chain) (Twaiq et al. 2003). The amount of gasoline fraction will increase with the decrease of that of diesel fraction in the conversion of palm oil.

The catalytic cracking of palm oil using a fixed-bed reactor and zeolite HZSM-5 as a catalyst at a temperature of $400^{\circ} \mathrm{C}$ produces hydrocarbons with a gasoline fraction of 40-70\% (Leng 1999). Conversion of palm oil with HZSM-5 catalyst primarily involve cracking and deoxygenation. The catalytic conversion of palm oil using composite micro-mesoporous zeolite as a catalyst in a fixed-bed reactor system operated at a temperature of $450^{\circ} \mathrm{C}$ produced gasoline fraction of 48 wt.\% of 99 wt.\% converted palm oil (Sang 2003). Conversion of palm oil using HZSM-5 catalyst resulted in a similar result as that using $\beta$-zeolite and Y-zeolite (USY-zeolite) catalysts. The conversion can reach $99 \%$ with the gasoline fraction of $28 \mathrm{wt} \%$ (Twaiq et al. 1999). The results of these studies concluded that zeolite-based catalysts, especially the type of HZSM-5 is a promising catalyst to convert palm oil to produce gasoline fraction and selective for aromatic compounds as well as a low coke formation.

The catalytic conversion process of palm oil with catalyst $\mathrm{Ni} /$ zeolite using nitrogen as a carrier gas only produced gasoline and diesel fractions of $27.5 \%$ and $36.08 \%$, respectively (Handoko 2006). In this study, nitrogen was no longer used due to its inert properties, and replaced by hydrogen which has dual functions as a reducing agent for catalyst and cracking agent for palm oil. The catalytic cracking of palm oil in this study used the catalysts based on the utilization of Indonesia natural zeolite as a smart material, $\mathrm{Ni}$ /zeolite, which were prepared by wetness impregnation method with active metal contents of $2-10 \% \mathrm{Ni}$ at various reaction temperatures $\left(400-500^{\circ} \mathrm{C}\right)$ in order to get a renewable and environmentally friendly bio-fuel along with its characteristics and performance.

\section{Materials and Methods}

\subsection{Materials}

Indonesian natural zeolite was obtained from PT. Zeolite Prima (Yogyakarta, Indonesia). The catalyst $\mathrm{Ni}$ /zeolite catalyst prepared by wetness impregnation method using a solution of nickel nitrate hexahydrate $\mathrm{Ni}\left(\mathrm{NO}_{3}\right)_{2} \cdot 6 \mathrm{H}_{2} \mathrm{O}$ (E. Merck) as a metal precursor with $\mathrm{Ni}$ content of 2-10 wt.\%. The details of the catalyst preparation and characterization was reported earlier (Kadarwati and Wahyuni, 2011). Hydrogen, nitrogen, and oxygen gases (99.9\% purity) were purchased from PT. Samator Gas (Semarang, Central Java).

Palm oil was obtained from a traditional market in Semarang, Central Java, in the form of cooking oil. Before undergo a catalytic craking process, palm oil was pre-treated with potassium methoxide in order to obtain the methyl ester of palm oil by reacting potassium methoxide generated from the reaction of potassium hydroxide (99.5\%, E.Merck) with methanol (99.8\%, E.Merck).

\subsection{Catalytic cracking of palm oil}

Catalytic cracking reaction in this study was carried out in a fixed-bed reactor system (Fig. 1). 5 grams of catalyst (in granular form) was placed in the reactor column and then heated to a temperature of $400-500^{\circ} \mathrm{C}$ with hydrogen gas with a flow rate of $50 \mathrm{~mL} / \mathrm{min}$. After reaching the desired temperature, $25 \mathrm{~mL}$ of the methyl ester of palm oil was quickly heated up and the vapour went together with hydrogen through catalyst bed. The product then condensed in a ice condenser equipped with a cooling coil for a better product condensation. After a 60-minutes reaction, reaction was stopped and the system was cooled down. The product obtained was collected and weighed for further analysis. 


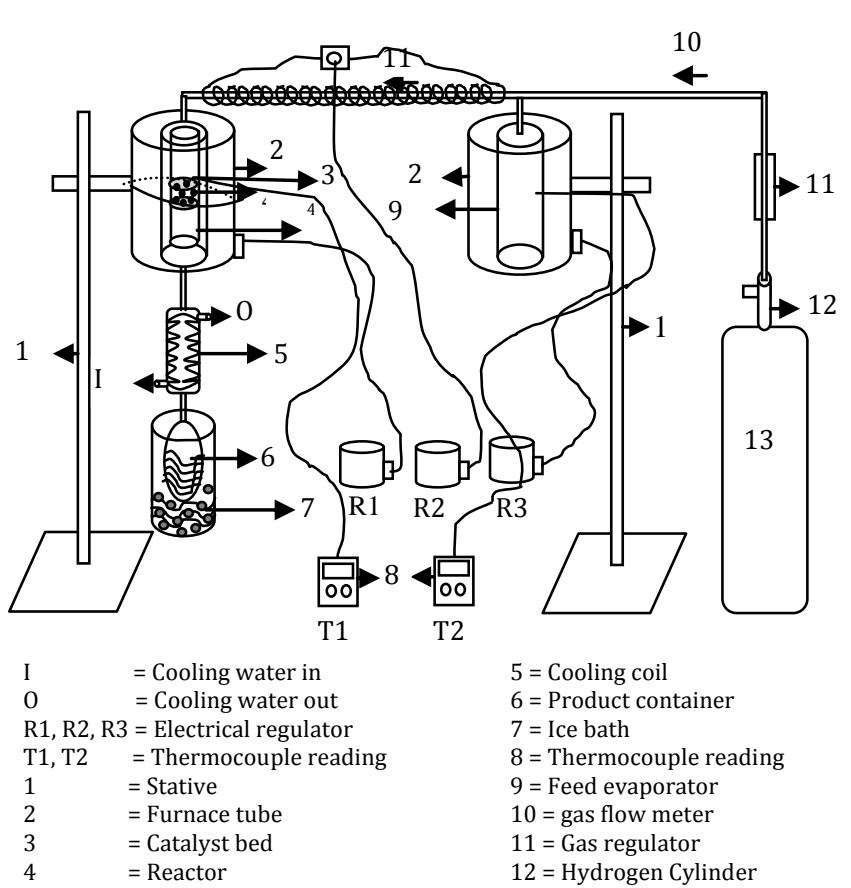

Fig. 1 The fixed-bed reactor system used in the catalytic cracking experiments

\subsection{Analyses}

The liquid product was analysed using Gas Chromatography (GC) Agilent Technologies 6820 equipped with a semipolar HP5 column (length $30 \mathrm{~m}$, diameter $0.32 \mathrm{~mm}$ ), and a FID detector. The liquid product with the highest yield was further analysed by using Gas Chromatography QP2010S SHIMADZU equipped with MS detector, Rastek RXi-5ms column (length $30 \mathrm{~m}$, internal diameter $0.25 \mathrm{~mm}$ ), and He gas as a carrier gas to determine the compounds in the liquid product (bio-fuel), and using a bomb calorimeter to determine the physical properties of the liquid product. The bio-fuel obtained at the best condition was also tested in a 4-strike engine to measure its compatibility of the bio-fuel produced as a fuel and/or as a coblending fuel.

\subsection{Calculation}

Yield is defined as the weight of liquid product obtained in each xperiment divided by the weight of methyl ester of palm oil input.

Yield $(\%)=\frac{\text { Wriquid product }}{\text { Winput }} \times 100$

Gasoline fraction is defined as the weight of hydrocarbon with $\mathrm{C}_{6}-\mathrm{C}_{9}$ (detected by GC-MS) divided by the weight of methyl ester of palm oil input.
Gasoline fraction $(\%)=\frac{W_{\text {CSE }}-c Q}{\text { Winput }} \times 100$

\section{Results and Discussion}

3.1 Effect of temperatures and nickel content on the yield of bio-fuel

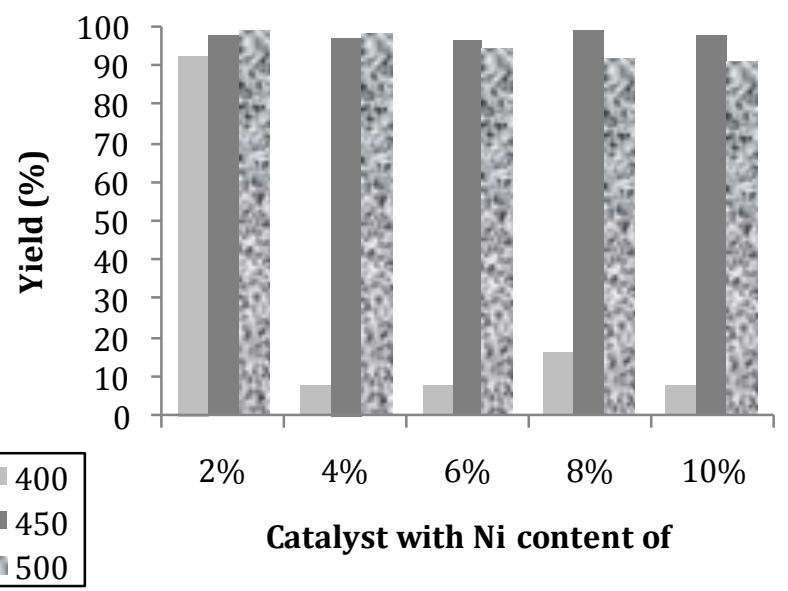

Fig. 2 The yield of bio-fuel in the catalytic cracking of methyl ester of palm oil in a fixed-bed reactor system at different temperatures (400$500^{\circ} \mathrm{C}$ ) using $\mathrm{Ni} /$ zeolite catalysts with different $\mathrm{Ni}$ content (2-10\%)

The details of the preparation of $\mathrm{Ni} /$ zeolite catalysts by wetness impregnation method with different $\mathrm{Ni}$ content and their characteristics were described elsewhere (Kadarwati and Wahyuni 2011). This paper is focusing on the activity of the prepared catalysts in the catalytic cracking process of palm oil. Fig. 2 shows the yield of the liquid product obtained at different process temperatures $\left(400-500^{\circ} \mathrm{C}\right)$ using $\mathrm{Ni} /$ zeolite catalyst with different $\mathrm{Ni}$ content ranging from $2 \%$ to $10 \%$. By increasing temperature, it was observed that the yield is considerably independent to the metal active content. Even, Ni-2/zeolite catalyst showed an almost constant yield by increasing temperature from $400^{\circ} \mathrm{C}$ to $500^{\circ} \mathrm{C}$. For catalysts with a higher Ni content (4-10\%), at $400^{\circ} \mathrm{C}$ it was shown that the yield was low. This is probably related to the amount of $\mathrm{Ni}$ metal loaded on the surface of the zeolite. The increase in the metal content would cause agglomeration of the metal on the surface of the support thus decreasing the specific surface area of the catalyst as a whole. This will lead directly to the decrease in the number of active sites of the catalyst. It can be shown from this study that the increase in the amount of $\mathrm{Ni}$ metal loaded is not followed by an increase in the activity of the catalyst. It was also pointed out by the decrease in acidity and porosity of the catalysts with an increased Ni loaded (Kadarwati and Wahyuni 2011). In addition, an increasing Ni loaded will increase the number of Lewis 
acid sites but is accompanied by a decrease in Bronsted acid sites which play a greater role in the process of cracking due to its function in binding and activating the methyl ester of palm oil. Thus, the bio-fuel produced at $500^{\circ} \mathrm{C}$ using $\mathrm{Ni}-2 /$ zeolite catalyst was further analyzed using GC-MS to investigate the compounds and also using calorimeter to investigate the physical characteristics.

The selectivity of desired product (in this study, the desired product is gasoline fraction) tends to decrease by increasing the active metal loaded at the surface of support (zeolite) (Siregar and Amin 2006) even though the yield might be similar. It might be caused by the size and the increasingly diverse active sites of the catalyst as a result of the rearrangement of the morphological structure of the catalyst due to the inclusion of active metals $\mathrm{Ni}$ in large quantities. The balance of solid structure would be disturbed by the presence of metal loaded, especially in a considerable amount.

Catalytic cracking process of methyl ester of palm oil into bio-fuel involves many complex reactions; even might generate hundreds of new compounds during the reaction involving multiphase reactions. These reactions are not only influenced by the presence of a catalyst, but also influenced by the thermal reaction. For this reason, the higher the temperature might give the greater conversion. This phenomenon occurs due to the diffusion process. Before the catalytic conversion occurs, the methyl ester of palm oil will first diffuse toward the catalyst pores. Upon entering the inner pores of the catalyst, the reaction will occur in the catalyst pores followed by diffusion of products in the gas phase leaving the surface of the catalyst. However, the effect of temperature makes energy reactant molecules increases. As a result, the movement of the active molecule will hinder the process of diffusion. At high temperatures, the rate determining step is the diffusion phase reactants on the catalyst surface (Siswanto et al. 2008).

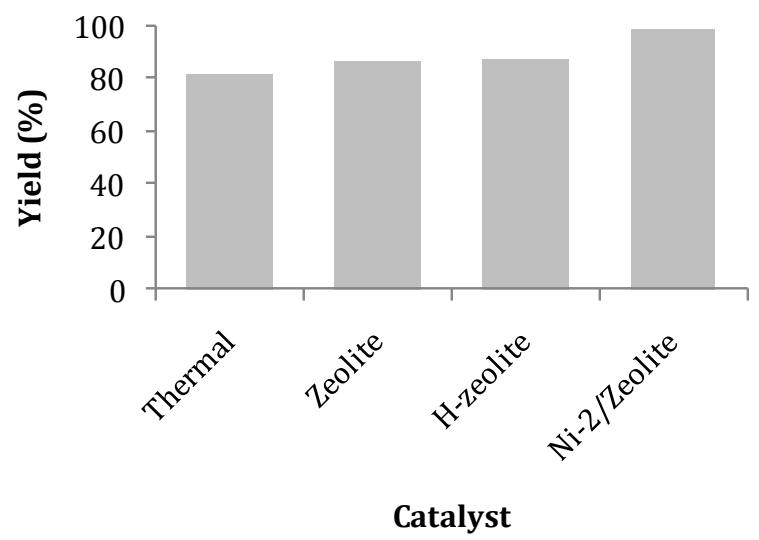

Fig. 3 The yield of bio-fuel in the catalytic cracking of methyl ester of palm oil in a fixed-bed reactor system at a temperature of $500^{\circ} \mathrm{C}$ with different catalyst.
Different results were obtained by Wijanarko et al. (2006) who used $\gamma$-alumina as catalyst. He and coworkers found the lower optimum temperature of the catalytic cracking of palm oil into gasoline fraction. However, the high thermal stability of zeolite compared to that of $\gamma$-alumina would make it more beneficial for commercial meaning in the exploration of renewable bio-fuel. In addition, the abundant availability and the inexpensive price of zeolite are other advantages of utilization of zeolite.

To see the real effect of catalyst on the catalytic cracking, the blank experiments were carried out for comparison. The yield of bio-fuel product using Ni$2 /$ zeolite, untreated zeolite, and pre-treated zeolite $(\mathrm{H}-$ zeolite) at $500^{\circ} \mathrm{C}$ is depicted in Fig. 3. It was confirmed that at $500^{\circ} \mathrm{C}$ the role of thermal reaction is significant. The presence of $\mathrm{Ni}-2 /$ zeolite catalyst could only slightly increase the yield of bio-fuel produced. However, it could be expected that the presence of catalyst could increase the selectivity of the gasoline fraction over the whole product.

\subsection{GC-MS analysis}

Table 1 provides an overview of the compounds in the bio-fuel sample produced at $500^{\circ} \mathrm{C}$ by using $\mathrm{Ni}$ 2 /zeolite catalyst. Of the ten peaks which were observed on the chromatogram, three of which cannot be detected by MS i.e. the peak number 1 in 1.5 minutes retention time, peak number 2 at 1.8 retention time and peak number 6 with a retention time of 7.1 minutes. This is possible because of a very weak peak intensity which indicates the low concentration of the corresponding compound.

Tabel 1

Compounds in the bio-fuel sample produced at $500^{\circ} \mathrm{C}$ using $\mathrm{Ni}$ 2/zeolite catalyst detected by GC-MS

\begin{tabular}{ccl}
$\begin{array}{c}\text { Retention time } \\
\text { (min) }\end{array}$ & \multicolumn{1}{c}{ Mr } & Name of compound \\
\hline 2,160 & 46,0 & Formic acid \\
2,495 & 60,0 & Acetic acid \\
3,180 & 88,05 & 1,4 -dioxan \\
7,285 & 160,0 & Hexanoic acid \\
7,405 & 94,1 & Phenol \\
8,910 & 130 & Heptanoic acid \\
9,010 & 108 & $p$-Cresol \\
\hline
\end{tabular}

The Ni/zeolite catalyst has Lewis and Bronsted acid sites that allow the hydrogenation process which could result in bonding cleavages. The high content of acid 
sites on the catalyst causes hydrogenated sustainable cracking reaction so that the products detected by GC-MS were predominantly $\mathrm{C}_{2}$ products. Aromatic products which usually dominate the results of palm oil hydrogenated-catalyzed cracking process as it has been reported by Siregar and Amin (2006) did not occur. In this study, such products was only about $10-12 \%$.

\section{Tabel 2}

The composition of bio-fuel produced from catalytic cracking of methyl ester of palm oil at $500^{\circ} \mathrm{C}$ using $\mathrm{Ni}-2 /$ zeolite catalyst

\begin{tabular}{cc} 
Fraction & Yield (\%) \\
\hline $\mathrm{C}_{2}-\mathrm{C}_{3}$ & 80.23 \\
$\mathrm{C}_{4}-\mathrm{C}_{5}$ & 1.42 \\
$\mathrm{C}_{6}-\mathrm{C}_{9}$ & 18.35 \\
\hline
\end{tabular}

Table 2 shows that the bio-fuel produced from the catalytic cracking of methyl ester of palm oil at $500^{\circ} \mathrm{C}$ using $\mathrm{Ni}-2$ /zeolite catalyst was predominated by light fraction. The product was not in gasoline fraction. Gasoline fraction has a range of number of carbon atoms 5-10 (Nasikin et al. 2009). The high yield of light products might be caused by the high cracking activity of the zeolite carrier as a result of the high acidity of the zeolite. Such conditions are not favored in the production of liquid fuels because it would give a low yield. Thus the yield of bio-diesel produced from this study only $18,35 \%$. These results are lower than those obtained Wijanarko et al. (2006) who reported that the yield of gasoline fraction obtained from catalytic cracking of palm oil catalysed by $\gamma$-alumina was $45.4 \%$. However, the bio-fuel obtained from his study contained a lot of heavy fractions. It is clear tha the cracking activity of zeolite-based catalyst is higher that that of alumina based.

The analysis result using GC-MS showed that biofuel produced at $500^{\circ} \mathrm{C}$ using $\mathrm{Ni}-2$ /zeolite catalyst contained cyclic compounds, carboxylic compounds, and paraffinic compounds with a total amount more than $20 \%$.This result is similar to that reported by Wijanarko et al. (2006), Farouq et al. (1999), and Farouq et al. (2003). From these results, it could be confirmed that the pure paraffinic compounds in gasoline fraction which are in composition range of commercial gasoline are heptanoic acid and hexanoic acid, whereas the aromatic compounds are $p$-cresol and phenol.

It is expected that the active sites of the catalyst could play an important role to break the double bond of oleic acid. Breaking the double bond is easier than the single bond. In this case, the methyl ester molecules can enter the pores of the catalyst with a diameter of \pm 0.56 because the longitudinal diameter (about 5.3 to $7.4^{\circ} \mathrm{A}$ ) and the chain length of the methyl esters (about 30-45 ${ }^{\circ}$ A) are smaller than the pores of the catalyst (Nasikin et al., 2009). Unsaturated molecules such as methyl ester of oleic acid are not favored in the bio-fuel because it is prone to react with impurities which are present in fuels or even with other methyl esters of oleic acid, forming undesirable polymer molecules (Idem et al., 1997).

\subsection{Physical properties of bio-fuel}

To evaluate the bio-fuel produced in the catalytic cracking process at $500^{\circ} \mathrm{C}$ using $\mathrm{Ni}-2$ /zeolite catalyst, the measurement on its physical properties has been conducted. The physical properties inlude density, viscosity, flash point and specific gravity as summarized in Table 3. The density of the bio-fuel was lower than that of the methyl esters of palm oil which is down from $0.996 \mathrm{~g} / \mathrm{cm}^{3}$ for he methyl ester to $0.88 \mathrm{~g} / \mathrm{cm}^{3}$ for the bio-fuel. It indicates that the cracking reaction actually occurs as evidenced by a decrease in the density of the product due to the production of lighter hydrocarbons fraction, besides indicated by the appearance of new peaks with retention times less than 14 minutes in the GC chromatogram. Flash point and specific gravity are also important characteristics of bio-fuel. The bio-fuel product has a flash point and a specific gravity that was only slightly higher than the commercial gasoline (commercial petrol). Of the four physical characteristics analysed in this study, it was shown that the bio-fuel produced in this study did not meet the standards of fuels yet. However, it may be indicated that the physical specifications of bio-fuel produced in this work were similar to commercial gasoline. These results complemented the results reported by Widjanarko et al. (2006) which measured the density and viscosity of biofuel produced using $\gamma$-alumina catalyst at $340^{\circ} \mathrm{C}$ for 1.5 hours reaction time. it had a density and viscosity which is very close to commercial gasoline specifications.

Tabel 3

Physical properties of the bio-fuel produced in the catalytic cracking of methyl ester of palm oil at $500^{\circ} \mathrm{C}$ using $\mathrm{Ni}-2 /$ zeolite catalyst

\begin{tabular}{lcc}
\multicolumn{1}{c}{ Properties } & Commercial petrol & Bio-fuel \\
\hline Densitas $\left(\mathrm{g} / \mathrm{cm}^{3}\right)$ & 0.77 & 0.88 \\
Viskositas $(\mathrm{P})$ & $3.70 \times 10^{-3}$ & $4.60 \times 10^{-3}$ \\
Titik Nyala $\left({ }^{\circ} \mathrm{C}\right)$ & 60 & 64.5 \\
Specific Gravity $(\mathrm{g} / \mathrm{mL})$ & 0.76 & 0.88 \\
\hline
\end{tabular}

\subsection{Performance test of fuel blending in 4-strike engine}

Table 4 shows some parameters of fuel performance including bio-fuel produced in this work and commercial gasoline (petrol). In this study, the performance parameters of pure bio-fuel were not determined due to the limitation of the engine used in the performance test. The test was carried out for the 
mixture of commercial gasoline (petrol) and bio-fuel with the ratio of $9: 1$ and $3: 1$. It was shown that the biofuel product still had a low performance compared to the gasoline did. The mixture of commercial gasoline and bio-fuel product with a ratio of 9:1 was able to produce a calorific value of $10 \%$ lower than that of the commercial gasoline (petrol) did, whereas the mixture of commercial gasoline and bio-fuel product with a ratio of $3: 1$ gave a calorific value of $11 \%$ lower than the commercial gasoline (petrol) did.

\section{Tablel 4}

The results of the performance test of commercial gasoline (petrol) and its mixtures with bio-fuel in the 4-strike engine (RPM 8000, breaker RPM 5000)

\begin{tabular}{|c|c|c|c|c|c|c|}
\hline \multirow[b]{2}{*}{ Parameter } & \multicolumn{6}{|c|}{ Type of Fuel } \\
\hline & \multicolumn{2}{|c|}{ Petrol } & \multicolumn{2}{|c|}{$\begin{array}{c}\text { Petrol:Bio- } \\
\text { fuel } \\
9: 1\end{array}$} & \multicolumn{2}{|c|}{$\begin{array}{c}\text { Petrol:Bio-fuel } \\
\text { 3:1 }\end{array}$} \\
\hline $\begin{array}{l}\text { Calorific } \\
\text { value }\end{array}$ & \multicolumn{2}{|c|}{$10,674.60$} & \multicolumn{2}{|c|}{$9,745.53$} & \multicolumn{2}{|c|}{$9,509.43$} \\
\hline (KCal/kg) & & & & & & \\
\hline $\begin{array}{l}\text { Tortion } \\
\text { (N.m) }\end{array}$ & \multicolumn{2}{|l|}{1.10} & \multicolumn{2}{|l|}{3.22} & \multicolumn{2}{|l|}{0.78} \\
\hline $\begin{array}{l}\text { Consumption } \\
\text { time per } 2 \\
\mathrm{~mL}(\mathrm{~s})\end{array}$ & \multicolumn{2}{|l|}{7.87} & \multicolumn{2}{|l|}{9.17} & \multicolumn{2}{|l|}{9.02} \\
\hline AVR M/s & \multicolumn{2}{|l|}{10.66} & \multicolumn{2}{|l|}{11.37} & \multicolumn{2}{|l|}{13.64} \\
\hline Gas & $\mathrm{CO}$ & 0.16 & $\mathrm{CO}$ & 0,10 & $\mathrm{CO}$ & 0.12 \\
\hline emission(\%) & $\mathrm{CO}_{2}$ & 0.59 & $\mathrm{CO}_{2}$ & 9.51 & $\mathrm{CO}_{2}$ & 7.00 \\
\hline \multirow[t]{2}{*}{ (load 10 kg) } & $\begin{array}{l}\text { UHC } \\
\text { (ppm) }\end{array}$ & 39.70 & $\begin{array}{l}\text { UHC } \\
\text { (ppm) }\end{array}$ & 60.6 & $\begin{array}{l}\text { UHC } \\
\text { (ppm) }\end{array}$ & 830 \\
\hline & $\mathrm{O}_{2}$ & 12.17 & $\mathrm{O}_{2}$ & 7.92 & $\mathrm{O}_{2}$ & 12.74 \\
\hline
\end{tabular}

Table 4 also shows that a mixture of commercial gasoline and bio-fuel with a ratio of 3:1 had a tortion value consumption time per $\mathrm{mL}$ which is close to the mixture of 9:1 and the commercial gasoline (petrol). It indicates that the fuel blend was quite effective. However, the 3:1 mixture had a very high value AVR with high $\mathrm{CO}$ and $\mathrm{O}_{2}$ emissions. It indicates that fuel burning of the 3:1 mixture was inefficient which is also evidenced by the high UHC (unsaturated hydrocarbons) particulate emissions. Thus, the 9:1 mixture had more similar performance to the commercial gasoline (petrol) with much lower $\mathrm{CO}$ and $\mathrm{O}_{2}$ emissions than the commercial gasoline (petrol) did. The low $\mathrm{O}_{2}$ emission showed that the burning of 9:1 mixture fuel was more efficient than that of commercial gasoline (petrol).

\section{Conclusions}

The catalytic cracking process of methyl esters of palm oil in a fixed-bed reactor system at $500^{\circ} \mathrm{C}$ using $\mathrm{Ni}-$ $2 /$ zeolite gave a bio-fuel yield of $99.0 \%$ with a yield of gasoline fraction of $18.35 \%$. The physical properties of the bio-fuel produced from this process in terms of density, viscosity, flash point, and specific gravity were lower but similar to the commercial gasoline (petrol). The performane test of the mixture of the commercial gasoline (petrol) and bio-fuel product showed that the 9:1 mixture had a similar performance to the commercial gasoline (petrol) with much lower $\mathrm{CO}$ and $\mathrm{O}_{2}$ emissions (62.5\% and $65.1 \%$ lower, respectively) and gave more efficient combustion compared to the commercial gasoline (petrol).

\section{Acknowledgements}

The authors would like to thank the Directorate of Research and Community Service of Directorate General of Higher Education of the Republic of Indonesia for research funding through National Strategic Research Grant 2011. The authors also thank Fitri Rahmwati, S.Si. and Puji Eka Rahayu, S.Si. for their valuable contribution to this study.

\section{References}

Choo, Y.M., Ma, A.N., (1996), Production technology of methyl esters from palm and palm kernel oils, PORIM Technology Bulletin 18

Demirbas, A., (2003), Fuel Conversional Aspect of Palm Oil and Sunflower, Energy Sources Journal, 25(5): 457-466

Handoko, D.S.P., (2006), Mekanisme Reaksi Konversi Katalitik Jelantah menjadi Senyawa Fraksi Bahan Bakar Cair dengan Katalis $\mathrm{Ni} / \mathrm{H}_{5}-\mathrm{NZA}$ dan Reaktor Flow-Fixed Bed, Jurnal Ilmu Dasar, 7(1): $42-51$

Idem, R.O., Katikaneni, S.P.R. dan Bakhsi, N.N., (1997), Catalytic Conversion of Canola oil to Fuels and Chemicals: Role of Catalyst Acidity, Basicity and Shape Selectivity on Product Distribution, Fuel ProcessTech., 51: 101-125

Kadarwati, S. dan Wahyuni, S., (2011), Preparasi, Karakterisasi, dan Uji Performa Katalis Ni/Zeolit dalam Proses Catalytic Cracking Minyak Sawit menjadi Bio-fuel, Proceeding Seminar Nasional Kimia dan Pendidikan Kimia III, ISBN 978-979-1533-85-0, p. 297308

Kloprogge, J.T., Doung Loc V., dan Frost, R.L., (2005), A Review of The Synthesis and Characterization of Pillared Clays and Related Porous Material for Cracking of Vegetable Oil to Produce Biofuel, Environmental Geology, 47(7): 967-981

Leng, T.Y., Mohamed, A.R., Bhatia, S., (1999), Catalytic Conversion of Palm Oil to Fuels and Chemicals, The Canadian Journal of Chemical Engineering, 77: 156-162

Nasikin, M., Susanto, B.H., Hirsaman, M.A., dan Wijanarko, A., (2009), Bio-gasoline from Palm Oil by Simultaneous Cracking and Hydrogenation Reaction over NiMo/zeolite Catalyst, World Applied Sciences Journal, 5 (Special Issue for Environment): 74-79

Sang, O.Y., (2003), Biofuel Production From Catalytic Cracking of Palm Oil, Energy Sources Journal, (25)9, pp. 859-869

Siregar, T.B. dan Amin, N.A.S., (2006), Catalytic Cracking Of Palm Oil To Gasoline Over Pretreated Cu-ZSM-5, Jurnal Teknologi, 44(F): 69-82 
Siswanto, D.Y., Salim, G.W., Wibisono, N., Hindarso, H., Sudaryanto, Y., dan Ismadji, S., (2008), Gasoline Production From Palm Oil Via Catalytic Cracking Using MCM-41: Determination Of Optimum Condition, ARPN Journal of Engineering and Applied Sciences, 3(6): 42-46

Twaiq, F.A., Zabidi, N.A.M. dan Bhatia, S., (1999), Catalytic Conversion of Palm Oil to Hydrocarbons: Performance of Various Zeolite Catalysts, Industrial and Engineering Chemistry Research, 38(9): 3230-3237

Twaiq, F.A., Zabidi, N.A.M. dan Bhatia, S., (2003), Liquid Hydrocarbon Fuels From Palm Oil By Catalytic Cracking over Aluminosilicate Mesoporous Catalyst With Various Si/Al Ratios, Microporous and Mesoporous Materials,64(1-3): 95-108
Twaiq, F.A., Zabidi, N.A.M. Mohamed, A.R. dan Bhatia, S., (2003), Catalytic Conversion of Palm Oil Over Meso Porous Aluminosilicate MCM 41 for The Production of Liquid Hydrocarbon Fuel, Fuel Processing Technology, 84(1-3): 105-120

Wijanarko, A., Mawardi, D.A., dan Nasikin, M., (2006), Produksi Biogasoline dari Minyak Sawit melalui Reaksi Perengkahan Katalitik dengan Katalis $\gamma$-Alumina, Makara Teknologi, 10(2), pp. 51-60

Yakovlev, V.A., Khromova, S.A., Sherstyuk, O.V., Dundich, V.O., Ermakov, D.Y., Novopashina, V.M., Lebedev, M.Y., Bulavchenko, O., Parmon, V.N., 2009, Development of new catalytic systems for upgraded bio-fules production from bio-crude-oil and biodiesel, Catal. Today, 144: 362-366 